\title{
PERBEDAAN WAKTU PEMBERIAN PAKAN YANG BERBEDA TERHADAP PERFORMA BENIH TAWES (Barbonimus gonoticus) DENGAN MENGGUNAKAN SISTEM RESIRKULASI
}

\section{THE TIME DIFFERENCE THE PROVISION OF FEED DIFFERENT TO SEED TAWES (Barbonimus gonoticus) PERFORMANCE BY USING THE RECIRCULATION SYSTEM}

\author{
Mahendra \\ Program Studi Akuakultur, Fakultas Perikanan dan Ilmu Kelautan \\ Universitas Teuku Umar \\ Korespondensi: mahendra@utu.ac.id
}

\begin{abstract}
ABSTRAK
Tujuan dari penelitian ini yaitu mengetahui pengaruh jarak waktu pemberian pakan terhadap performa benih tawes (Barbonimus gonoticus) dengan menggunakan sistem resirkulasi. Metode yang digunakan dalam peneliatian ini adalah metode eksperimental, rancangan percobaan yang digunakan adalah rancangan acak lengkap (RAL) dengan 4 perlakuan dan 3 kali pengulangan. Adapun Perlakuan-perlakuan tersebut yaitu: $\mathrm{P} 1=$ pemberian pakan 1 kali pada pukul $8.00, \mathrm{P} 2$ = pemberian pakan 2 kali sehari pada pukul $08.00,18.00, \mathrm{P} 3=$ pemberian pakan 3 kali sehari yaitu pada pukul $08.00 ; 12.00 ; 16.00$ dan $\mathrm{P} 4$ = pemberian pakan 4 kali sehari yaitu pada pukul $07.00 ; 11.00 ; 15.00,19.00$. Parameter yang diamati pada penelitian ini adalah laju pertumbuhan spesifik, pertumbuhan biomassa, pertumbuhan panjang mutlak, tingkat kelangsungan hidup, konversi pakan dan kualitas air. Hasil penelitian menunjukan bahwa frekuensi pemberian pakan yang berbeda memberikan hasil berpengaruh nyata terhadap parameter pertumbuhan spesifik, pertumbuhan panjang mutlak, konversi pakan dan tidak berpengaruh nyata terhadap tingkat kelangsungan hidup benih ikan tawes. Frekuensi pemberian pakan tertinggi terdapat pada perlakuan P4 dengan nilai laju pertumbuhan spesifik 2,074\%, pertumbuhan panjang relatif 0,952 $\mathrm{cm}$, konversi pakan 3,146 gram, sedangkan kelangsungan hidup yaitu 100\%.
\end{abstract}

Kata Kunci: Perbedaan waktu, pemberian pakan, performa, ikan tawes

\section{ABSTRACT}

The purpose of research is know the time difference the provision of feed different to seed tawes (Barbonimus gonoticus) performance by using the recirculation system. Methods used in this research is the experimental methods. The experiment used is random design complete (RAL) with four treatment and three times test. Treatment are $\mathrm{P} 1=$ the provision of feed 1 time a day at $8.00, \mathrm{P} 2$ $=$ the provision of feed 2 time a day at $08.00,18.00, \mathrm{P} 3=$ the provision of feed 3 time a day at $08.00 ; 12.00 ; 16.00$ and $\mathrm{P} 4=$ the provision of feed 4 time a day at $07.00 ; 11.00 ; 15.00,19.00$. Parameters observed in research is growth rate specific, Biomass growth, Growth long absolute, survival, conversion feed and water quality. The results of the study showed that appeasement time the provision of feed different results from had have real impact on parameter specific growth, Growth long absolute, conversion feed And not had have real impact on survival seed fish tawes. The time difference the provision of feed is highest in treatment $\mathrm{p} 4$ with value growth rate specific $2,074 \%$, Growth long absolute $0,952 \mathrm{~cm}$, conversion feed 3,146 gram, while survival $100 \%$.

Keyword: Barbonimus gonoticus, Performance, The Time Difference, The Provision of Feed 


\section{PENDAHULUAN}

Ikan tawes (Barbonimus gonoticus) atau dikenal dengan nama tawas atau lampam merupakan salah satu ikan budidaya air tawar asli Indonesia. Ikan ini bersifat herbivora sehingga menguntungkan bagi pembudidaya tradisional. Keunggulan lain dari ikan ini adalah dapat dipelihara di perairan payau sehingga dapat dikembangkan di tambak-tambak tradisional. Selain itu, tawes merupakan salah satu ikan konsumsi ekonomis yang harganya terjangkau oleh masyarakat (Bardach et al., 1992). Direktorat Jenderal Perikanan (1981) berpendapat bahwa pengembangan budidaya ikan tawes dimaksudkan untuk memenuhi ketahanan masyarakat akan sumber protein yang murah dan terjangkau oleh masyarakat. Permintaan ikan tawes di pasar tentunya harus sejalan dengan peningkatan produksi benih tawes, baik secara kualitas maupun kuantitas, sehingga akan dapat mencukupi permintaan masyarakat akan ikan tersebut. Produksi benih tawes dewasa ini tidak hanya dilakukan di balai-balai pembenihan ikan, tetapi juga telah dilakukan oleh masyarakat.

$$
\text { Manajemen pemberian pakan }
$$

merupakan salah satu usaha yang dilakukan untuk mendukung keberhasilan usaha budidaya, dengan manajemen pemberian pakan diharapkan agar pakan yang diberikan dapat dimanfaatkan oleh ikan secara efektif dan efisien sehingga menghasilkan pertumbuhan ikan yang optimal. Salah satu penerapan manajemen pemberian pakan adalah pengaturan waktu pemberian pakan yaitu berapa kali pakan diberikan dalam satu hari. Pembudidaya pada umumnya memberikan pakan pada ikan budidaya hanya menurut kebiasaan, tanpa mengetahui tentang kebutuhan nutrisi masing-masing ikan budidaya, baik itu kualitas, kuantitas dan waktu pemberian pakan yang tepat. Hal ini menyebabkan pakan yang diberikan kurang memberikan pertumbuhan yang optimal bagi ikan karena tidak sesuai dengan kebutuhan ikan. Manajemen pemberian pakan mengharuskan pakan yang diberikan kepada ikan harus tepat secara kualitas, kuantitas dan tepat waktu pemberiannya demi keberhasilan usaha budidaya. Pemberian pakan dengan waktu yang berbeda akan mempengaruhi pertumbuhan ikan (Hanief et al. 2014).
Oleh karena itu penelitian tentang perbedaan waktu pemberian pakan terhadap pertumbuhan dan kelulusanan hidup benih ikan tawes (Barbonimus gonoticus) dengan mengunakan resirkulasi perlu di lakukan. Penelitian ini bertujuan mengetahui perbedaan waktu pemberian pakan terhadap performa benih ikan tawes (Barbonimus gonoticus) dengan mengunakan resirkulasi dan untuk mengetahui perbedaan waktu pemberian pakan yang optimal terhadap performa benih ikan tawes (Barbonimus gonoticus) dengan mengunakan resirkulasi.

\section{METODE PENELITIAN}

Penelitian dilakukan dengan metode eksperimental menggunakan rancangan acak lengkap (RAL) dengan 4 perlakuan diulang sebanyak tiga kali. Perlakuan $1=$ waktu pemberian pakan satu kali sehari yaitu pada pukul 08.00 , perlakuan $2=$ waktu pemberian pakan dua kali sehari yaitu pada pukul 08.00 dan 18.00 , perlakuan $3=$ waktu pemberian pakan tiga kali sehari yaitu pada pukul 08.00 ; $12.00 ; 16.00$, perlakuan $4=$ waktu pemberian pakan empat kali sehari yaitu pada pukul 07.00; $11.00 ; 15.00$ dan 19.00 .

\section{Prosedur Penelitian}

Ikan yang digunakan adalah benih tawes dari pembenihan hasil produksi BBI. Benih tawes tersebut berumur 1,5 bulan dengan bobot rata-rata $\pm 3 \mathrm{~g}$ dan panjang standar rata-rata $\pm 5 \mathrm{~cm}$. Jumlah benih yang digunakan untuk tiap perlakuan dan ulangan adalah sebanyak 20 ekor. Benih tawes terlebih dahulu diadaptasikan dalam bak fiber selama dua hari agar benih tersebut diharapkan mampu menyesuaikan kondisi dengan lingkungan barunya. Masa pemeliharaan benih tawes adalah selama 40 hari

Wadah yang digunakan adalah jeregen berukuran $(\mathrm{P} 30 \times \mathrm{L} 20 \times \mathrm{T} 15) \mathrm{cm}^{3}$. Wadah (jeregen) tersebut ditempatkan di dalam ruang Hechery Fakultas Perikanan dan Ilmu Kelautan Universitas Teuku Umar. Jumlah wadah yang digunakan untuk penelitian ini sebanyak 12 buah. Wadah tersebut mengunakan resirkulasi yang bertujuan untuk menambah suplai oksigen. Air dalam wadah diisi setinggi $15 \mathrm{~cm}$. 
Pada bagian atas wadah diberi penutup berupa jaring untuk mencegah ikan meloncat keluar dari wadah budidaya.
Pertambahan Panjang

Pertambahan panjang menurut Soeprapto (2009) dihitung dengan rumus

Mesin Sanyo

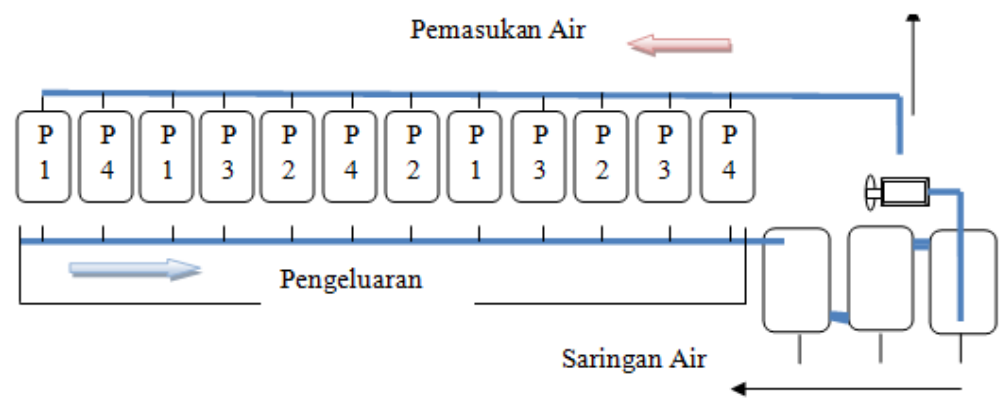

Gambar 1. Sistem resirkulasi

Pakan yang diberikan dalam penelitian ini mengunakan pelet berwarna HI-PROVITE F-999. Kandungan nutrisi pada pakan tersebut adalah sebagai berikut: protein $35 \%$; lemak 2\%; serat 3\%; abu $13 \%$ serta air $12 \%$. Pemberian pakan dilakukan dengan metode at satiation, yakni pakan diberikan sedikit demi sedikit sampai $80 \%$ ikan tidak lagi merespon pakan yang diberikan. Jumlah pakan pada setiap kali pemberian dilakukan penimbangan sehingga dapat diketahui jumlah pakan yang diberikan untuk setiap waktunya dan jumlah total pakan yang diberikan selama masa pemeliharaan. Air yang digunakan sebagai media pemeliharaan dalam penelitian ini adalah air yang berasal dari sumur bor yang langsung di alirkan ke wadah pemberiharaan. Resirkulasi selama 24 jam tanpa henti bertujuan untuk mengsuplai oksigen dan mengangkat kotoran yang mengendap di dasar agar tidak menumpuk sehingga kualitas air tetap terjaga.

\section{Parameter Uji}

Kelangsungan hidup

Kelangsungan hidup menurut Taqwa (2008) dihitung dengan rumus sebagai berikut:

$$
\mathrm{SR}=\mathrm{Nt} / \mathrm{No} \times 100 \%
$$

\section{Keterangan:}

SR: Kelangsungan hidup (\%)

Nt: Jumlah udang pisang pada waktu $t$ (individu)

No: Jumlah udang pisang pada awal percobaan (individu)

$$
\mathrm{L}=\mathrm{L}_{1}-\mathrm{L}_{0}
$$

Keterangan:

$\mathrm{L}=$ Pertambahan panjang rata-rata individu

L1= Panjang rata-rata akhir uji ikan tawes

$\mathrm{L} 0=$ Panjang rata-rata awal uji ikan tawes

Laju Pertumbuhan Spesifik (SGR)

Laju pertumbuhan spesifik menurut Hana (2009) dihitung dengan menggunakan rumus sebagai berikut:

$$
\mathrm{SGR}=\frac{\operatorname{Ln} \mathrm{Wt}-\operatorname{Ln} \mathrm{W} 0}{\mathrm{t}} \times 100 \%
$$

Keterangan:

SGR: Laju pertumbuhan spesifik

LnWt: Berat benih tawes akhir penelitian

LnW0: Berat benih tawes awal penelitian

t: Waktu penelitian (lama penelitian)

\section{Konversi Pakan (FCR)}

Menurut Mokoginta et al. (1995), rasio konversi pakan (feed conversion ratio, FCR) dapat dihitung menggunakan rumus sebagai berikut:

$$
\mathrm{FCR}==\frac{\mathrm{F}}{(\mathrm{Wt}-\mathrm{Wo})+\mathrm{D}} \times 100 \%
$$

Keterangan:

$\mathrm{FCR}=$ Feed conversion ratio

$\mathrm{F}=$ Jumlah pakan yang dihabiskan $(\mathrm{kg})$

$\mathrm{W}_{\mathrm{t}}=$ Biomassa ikan akhir pemeliharaan $(\mathrm{kg})$

$\mathrm{W}_{\mathrm{d}}=$ Biomassa ikan mati $(\mathrm{kg})$

$\mathrm{W}_{\mathrm{o}}=$ Biomassa ikan awal pemeliharaan $(\mathrm{kg})$ 


\section{HASIL DAN PEMBAHASAN}

Kelangsungan Hidup

Pengamatan terhadap tingkat kelangsungan hidup benih Tawes (Barbonimus gonoticus) selama pemeliharaan 40 hari dengan menggunakan waktu pemberian pakan dengan sistem resirkulasi air di lihat pada Gambar 2.

Hasil perhitungan ANOVA menunjukan bahwa waktu pemberian pakan dengan menggunakan sistem resirkulasi air tidak berpengaruh nyata terhadap kelangsungan hidup benih ikan tawes. Karena selama penelitian ikan tawes yang diujicobakan tidak mengalami kematian.

Effendie (1997) menyatakan bahwa survival rate atau derajat kelangsungan hidup dipengaruhi oleh faktor biotik yaitu persaingan, parasit, umur, predator, kepadatan dan penanganan manusia, sedangkan faktor abiotik adalah sifat fisika dan kimia dalam perairan. Kepadatan yang tinggi akan mengakibatkan menurunnya kualitas air terutama kandungan oksigen terlarut dan konsentrasi amoniak. Penurunan kualitas air bisa menyebabkan stres pada ikan, bahkan apabila penurunan mutu air telah melampaui batas toleransi maka akan berakibat pada kematian. Selain itu penurunan mutu air juga dapat mempengaruhi nafsu makan ikan. Saat nafsu makan berkurang, asupan pakan ke dalam tubuh ikan pun berkurang sehingga energi untuk pemeliharaan dan pertumbuhan tidak terpenuhi. Hal ini bila berlangsung lama akan menyebabkan kematian.

\section{Pertambahan Panjang}

Pertumbuhan rata-rata panjang relatif benih ikan Tawes (Barbonimus gonoticus), selama 40 hari dapat di lihat pada Gambar 3. Hasil perhitungan ANOVA menunjukan bahwa perlakuan waktu pemberian pakan dengan menggunakan sistem resirkulasi air berpengaruh nyata terhadap pertumbuhan panjang relatif benih ikan Tawes. Nilai pertumbuhan panjang relatif maksimum terdapat pada perlakuan $\mathrm{P} 4$ yaitu $0,952 \mathrm{~cm}$, diikuti P3 dengan rata-rata $0,341 \mathrm{~cm}$ selanjutnya $\mathrm{P} 2$ yaitu $0,426 \mathrm{~cm}$ dan tanpa perlakuan (P0) sebesar $0,502 \mathrm{~cm}$. Berdasarkan hasil uji lanjut Beda Nyata Terkecil (BNT) pada selang kepercayaan 95\%, diperoleh hasil berbeda sangat nyata antara perlakuan P3 dengan perlakuan $\mathrm{P} 4$, selanjutnya diperoleh hasil berbeda nyata antara perlakuan P2 dengan perlakuan $\mathrm{P} 3$, dan $\mathrm{P} 1$ dengan $\mathrm{P} 4$ serta terdapat hasil tidak berbeda nyata antara perlakuan P3 dengan perlakuan P2, P3 dengan $\mathrm{P} 1$ dan P2 dengan P1.Pertumbuhan panjang relatif benih ikan tawes merupakan selesih nilai panjang ikan pada akhir penelitian dengan awal penelitian. Hasil pertumbuhan panjang relatif ikan tawes selama penelitian berkisar antara 0,502-0,952 cm. Berdasarkan hasil uji ANOVA selang kepercayaan 95\% dengan perlakuan frekuensi pemberian pakan (1, 2, 3 dan 4 kali sehari) menggunakan system resisrkulasi air memberikan pengaruh yang sangat nyata terhadap pertumbuhan panjang mutlak benih ikan tawes. Adanya pertambahan menunjukkan bahwa pakan yang diberikan selama penelitian telah melebihi kebutuhan pokok ikan itu sendiri untuk pemeliharaan tubuhnya (maintenance) sehingga selebihnya digunakan untuk pertambahan panjang badan ikan tawes.

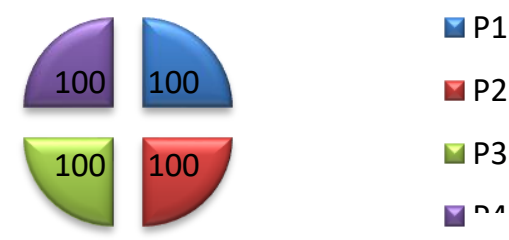

Gambar 2. Kelangsungan hidup benih i tawes

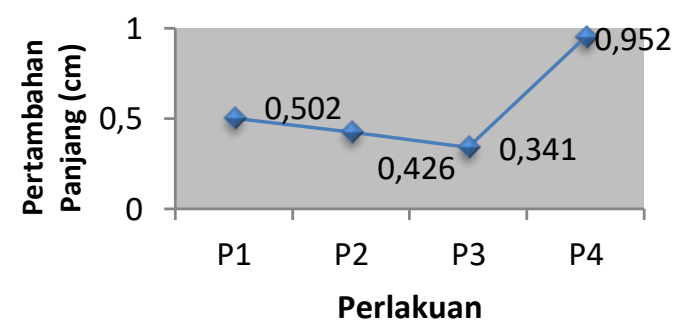

Gambar 3. Pertumbuhan panjang relatif benih ikan tawes

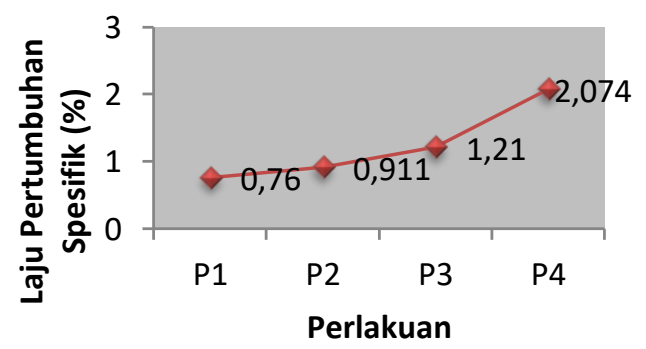

Gambar 4. Laju pertumbuhan spesifik benih ikan tawes 
Laju Pertumbuhan Spesifik

Perlakuan waktu pemberian pakan menunjukkan pertumbuhan rata-rata SGR yang berbeda pula serta dapat di lihat pada Gambar 4. Hasil perhitungan ANOVA menunjukan bahwa perlakuan waktu pemberian pakan dengan menggunakan sistem resirkulasi air berpengaruh nyata terhadap laju pertumbuhan spesifik benih ikan tawes. Berdasarkan hasil uji lanjut Beda Nyata Terkecil (BNT) pada selang kepercayaan 95\% diperoleh hasil berbeda sangat nyata antara perlakuan P1 dengan perlakuan P3 selanjutnya diperoleh hasil berbeda nyata antara perlakuan P1 dengan perlakuan P3 dan $\mathrm{P} 2$ dengan perlakuan $\mathrm{P} 3$, serta terdapat hasil tidak berbeda nyata antara perlakuan P1 dengan perlakuan $\mathrm{P} 2$, perlakuan $\mathrm{P} 1$ dengan Perlakuan P3 dan perlakuan P1 dengan perlakuan P4.

Hasil laju pertumbuhan spesifik ikan tawes tertinggi didapatkan pada perlakuan P4 yaitu frekuensi pemberian pakan 4 kali sebesar 2,074\%. Hal ini karena jumlah pakan yang diberikan sesuai dengan kapasitas tampung lambung ikan sehingga pakan yang diberikan dapat dikonsumsi dan dicerna dengan sempurna oleh ikan. Sesuai pernyataan Hanief et al. (2014) pemberian pakan tiga sampai empat kali sehari sesuai dengan kebutuhan konsumsi pakan untuk benih tawes sehingga menghasilkan pertumbuhan yang maksimal.

Pertumbuhan diartikan sebagai proses perubahan ukuran panjang, bobot atau volume pada periode tertentu. Selama pemeliharaan, bobot ikan tawes menunjukkan peningkatan untuk setiap perlakuan (Gambar 3). Adanya pertumbuhan menunjukkan bahwa pakan yang diberikan selama penelitian telah melebihi kebutuhan pokok ikan itu sendiri untuk pemeliharaan tubuhnya (maintenance) sehingga selebihnya digunakan untuk pertumbuhan. Hal tersebut sesuai dengan pernyataan Rohman (2015) yang menjelaskan bahwa pertumbuhan terjadi apabila ada kelebihan input energi dan protein berasal dari makanan. Selain itu, pergantian air selama pemeliharaan mampu menjaga kualitas air.

Sementara itu pertumbuhan terendah terdapat pada perlakuan P1 yang frekuensi pemberian pakannya 1 kali yaitu sebesar $0,74 \%$. Hal ini karena pemberian pakan 1 kali sehari akan menyebabkan ikan kekurangan asupan nutrisi pada tubuh ikan itu sendiri.

\section{Konversi Pakan}

Hasil laju konversi pakan (FCR) benih ikan tawes yang dipelihara selama 40 hari dapat dilihat pada Gambar 5. Hasil perhitungan ANOVA menunjukan bahwa waktu pemberian pakan dengan menggunakan sistem resirkulasi air berpengaruh nyata terhadap konversi pakan benih ikan tawes. Nilai FCR terbaik terdapat pada perlakuan P4 yaitu 3,14 gram, diikuti P3 dengan rata-rata 7,050 gram selanjutnya $\mathrm{P} 2$ yaitu 9,360 gram dan p1 sebesar 12,524 gram. Berdasarkan hasil uji lanjut Beda Nyata Terkecil (BNT) pada selang kepercayaan $95 \%$, diperoleh hasil berbeda sangat nyata antara perlakuan P3 dengan perlakuan P1, selanjutnya diperoleh hasil tidak berbeda nyata antara perlakuan $\mathrm{P} 4$ dengan perlakuan $\mathrm{P} 3, \mathrm{P} 4$ dengan $\mathrm{P} 2$, P3 dengan $\mathrm{P} 2, \mathrm{P} 3$ dengan $\mathrm{P} 1$ dan $\mathrm{P} 2$ dengan P1.

Nilai konversi (FCR) pakan menunjukkan seberapa $\mathrm{kg}$ pakan yang dihabiskan untuk menghasilkan $1 \mathrm{~kg}$ perubahan bobot biomassa (NRC, 1993). Nilai konversi pakan terbaik terdapat pada perlakuan P4 yaitu sebesar 3,146, dan nilai konversi pakan terendah terdapat pada perlakuan P1 yaitu 12,524. Perlakuan perbedaan waktu pemberian pakan memberikan pengaruh nyata $(p>0,05)$ terhadap konversi pakan benih ikan tawes selama masa pemeliharaan 40 hari. Nilai konversi pakan pada perlakuan P4 menunjukkan pemanfaatan pakan yang lebih optimal oleh ikan tawes.

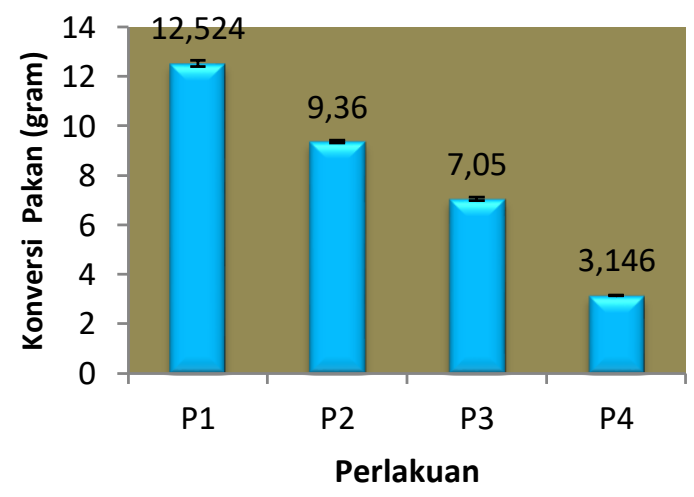

Gambar 5. Konversi pakan benih ikan tawes 


\section{KESIMPULAN}

Waktu pemberian pakan yang berbeda pada ikan tawes (1, 2, 3 dan 4 kali sehari) memberikan pengaruh yang nyata terhadap pertumbuhan ikan tetapi tidak memberikan pengaruh terhadap kelangsungan hidup benih ikan tawes. Nilai pertumbuhan spesifik benih ikan tawes yang optimal terdapat pada perlakuan P4 yaitu pemberian pakan 4 kali sehari.

\section{UCAPAN TERIMA KASIH}

Riset penulis dibiayai oleh Hibah Penelitian dari DIKTI, dan ucapan terima kasih kepada Instansi Universitas Teuku Umar khusunya LPPM dan Penjaminan Mutu serta Program Studi Akuakultur Fakultas Perikanan dan Ilmu Kelautan.

\section{DAFTAR PUSTAKA}

Arddhiagung, G.F. 2010. Kinerja Produksi Beih Ika Patin Pangasius hypophthalmus. Ukuran 3 Inchi dalam Sistem Resirkulasi degan Debit Air Yang Berbeda. Bogor: Departemen Budidaya Perairan Fakultas Perikanan Dan Ilmu Kelautan Institut Pertanian Bogor.

Bardach, J.E., Ryther and W. O. Mclarney. 1992. Aquaculture. Wiley Interscience.

Direktorat Jenderal Perikanan. 1981. Pembenihan Ikan Tawes (Puntius javanicus) dengan Stripping. Jakarta.

Effendie, M. I. 1979. Metode Biologi Perikanan. Bogor: Yayasan Dewi Sri.

Effendi H. 2000. Telaah Kualitas Air Bagi Pengelolaan Sumberdaya dan Lingkungan Perairan. Bogor: Fakultas Perikanan dan Ilmu Kelautan IPB.

Hana. 2009. Pengaruh Substitusi Pakan Mikrokapsul dari Tubifex sp. pada Penyapihan Awal terhadap Laju Ingesti, Pertumbuhan dan Sintasan Larva Ikan Gurami (Osphronemus gouramy Lac.) [Tesis]. Purwokerto: Universitas Jenderal Soedirman.

Hanief, M.A.R. Subandiyono. Pinandoyo. 2014. Pengaruh Frekuensi Pemberian Pakan Terhadap Pertumbuhan Dan Kelulushidupan Benih Tawes (Puntius javanicus). Journal of Aquaculture Management and Technology. 3 (3): 67-74.
Soeprapto, H. 2009. Pemberian Pakan Mikropartikel dan Pemuasaan terhadap Pertumbuhan Juvenil Udang Windu (Penaeus monodon) [Tesis]. Purwokerto: Universitas Jenderal Soedirman 